\title{
Sacred Functions of Musical Instruments in the Creative Syncretism of Shamanistic Ritual
}

\author{
Amanova Roza Aslanova', Mukhambetova Asiya Ibadulayevna², \\ Dzhanseitova Svetlana Sattarovna ${ }^{3}$ \\ ${ }^{1}$ PhD in Art History, Professor at the Kyrgyz-Turkish Manas University. Kyrgyz Republic, \\ Bishkek. Email: rza.amanova@gmail.com. \\ ${ }^{2}$ Sc.D in Art History, Professor at T. Zhurgenev Kazakh National Academy of Art \\ ${ }^{3}$ Doctor of philology, Professor of Kazakh National Conservatory after Kurmangazy.
}

Received November 10, 2017; Revised January 25, 2018; Accepted February 05, 2018; Published May o6, 2018.

\begin{abstract}
The study explores the spiritual and worldview aspects of shaman's ritualistic practice through the example of Central Asian Turkic tribes. We tried to show the magico-religious aspect of using the most widespread Kazakh and Kyrgyz musical instruments in the shamanic practice as a ritual that forms the artistic field in the general context of syncretic multi-element complex of shamanistic practice. This study considers the syncretism of creative principles in the shamanistic ritual, and the meanings of the sacred musical instruments (kobyz, tambourine, dombra, asatayak) used in the re shamanistic rituals of the nomadic Turkic religion Tengrianism. The ritualistic practice of shamans is interpreted as an artistic comprehension of the world, which not only records and reflects the reality, but also bears creative and forming principles, thus becoming an integral part of culture. At that, emphasis is placed on the key role of sacred musical instruments in the shamanistic ritual. The study reveals the spiritual and symbolic meaning of each key musical instrument in the shamanistic ritual separately and in the context of the syncretic complex of the shaman's ritualistic practice.
\end{abstract}

Keywords: Central Asian shamanism, shamanistic ritual, storytelling, Tengrism, shaman tambourine.

\section{Introduction}

Shamanism became famous as a Siberian and Central Asian religious phenomenon that was discovered and first described by people, who traveled across various regions of Central and Northern Asia. Later, when similar magico-religious practices were discovered in North America, Indonesia, Oceania, and other locations. It became obvious that shamanism was not a religious phenomenon specific to a particular area, but rather a stage of religious ideas development in general (Nicholson, 2014).

Siberia and Central Asia shamanism was part of a holistic religious worldview of Turks Tengrianism, where the Universe is divided into the Upper, Middle and Lower Worlds. As specialized ministers of the cult in Tengrianism, the shamans preserved the traditions of their ancestors. Deifying natural phenomena, Tengrianism did not contrast, like monotheistic religions, "this world" and "other world," but rather identified them. The world of spirits, invisible, but real, was a part of earthly life. Tengrists views were also characterized by the Hylozoism - everything had a soul, a mind. Thus, all the components of the Universe (people, animals, nature, spirits of ancestors) had to be treated with respect and attention - honored by rites and religious ceremonies, offered sacrifices (Bezertinov, 2006).

(c) AesthetixMS 2018. This Open Access article is published under a Creative Commons Attribution Non-Commercial 4.0 International License (http://creativecommons.org/licenses/by-nc/4.o/), which permits non-commercial re-use, distribution, and reproduction in any medium, provided the original work is properly cited. For citation use the DOI. For commercial re-use, please contact editor@rupkatha.com. 
In Turkic and Mongolian nations, people, engaged in shamanistic practices, were called "bakses". Different tribes interpreted this term differently. In Kazakh tribes, baksy was a person capable of entering an ecstatic state and communicating with another world. In the Karakalpak language, baksy means a person, who tells epic stories accompanied by the dutar; in Mongolian, it means a teacher. Turkmens translate it as a singer or musician; Altai people and Tatars - a craftsman; Uzbeks - a witchdoctor. In the ancient Uyghur language, it means scholar; in the Kyrgyz language - a shaman, who plays the komuz (Radlov, 1959).

Contemporaries regarded shamans as people, who knew the mysteries of nature, whose main peculiarity was their ability to communicate with the spirits, ask them for help and guidance, or ask them to intervene by possessing the body of the medium - the shaman. Such magical goals were achieved by special rituals that resembled dramatic miracle plays rather than practical and effective actions (Nicholson, 2014).

The shamanistic ritual is a tradition of shamanism - a special communication system based on the syncretism of syntactically ordered artistic means and realized in an altered state of consciousness that intensifies emotional and vivid perception (Novik, 1973). As an important component of a traditional culture, shamanistic ritual is a specific genre typical only for the tradition of shamanism, which combines canonical and improvised elements. The effect of all these components on the human mind and life show that the spiritual essence of various forms of art have become a part of their everyday life (Ksenofontov, 1991).

Cultural significance of the baksy art, including its musical component, is possible to comprehend and understand only through a comprehensive exploration of the worldview, as the baksy art is part of it. As performers of Tengrian rites, shamans were keepers of customs and traditions. Their artistic work is based on the syncretic unity of speech, songs, sounds of musical instruments, and dance moves, all united into a single rhythmic pattern.

The interest on the part of musicologists, cultural specialists, and philosophers in shamanism has grown in the last decades. In particular, they are interested in the phenomenon of a shaman as a spiritual all-rounder, whose practice has combined functions that applied to various spheres: religious cult, primitive science, medicine, music, and poetry. Shamans used their musical and poetic gift, and knowledge of myths and legends to combine the functions of a priest, healer, magician, diviner, musician, actor, singer, bearer of sacred knowledge, mentor, storyteller, advisor, and keeper of cultural traditions (Flaherty, 2014).

One has to investigate the aspects related to the mythological perception of the world and the place of humans therein in order to study the features of the artistic practice of Kazakh baksy, including its musical aspect (Margulan \& Lizunova, 1957). Shamanic musical instruments mentioned in the works of the most ancient Turkic writers. However, later scientific description was not devoid of one-sidedness and bias due to the lack of attention to the traditional Turkic religion Tengrianism (Valikhanov, 1961). Detailed descriptions of shamanic musical instruments in regards to their significance in the national musical culture often did not contain the sacred, religious aspect of their use (Eichhorn, 1963). Thus, we have to analyze the musical component in the general context of spiritual and worldview specificity of shamanistic practice of Central Asian Turks, which is important for gaining a better understanding and reconsidering the constants of ancient world perception. We have to study the multi-element structure of the shamanistic practice in terms of each of its elements, including the musical one. At this point it is necessary to keep in mind other integrally related aspects of shamanistic practice - magical, ceremonial, artistic, and utilitarian. 
This research is an attempt to present the magico-religious aspect of using the Kazakh and Kyrgyz musical instruments in shamanistic practice as one that forms the artistic field of shamanistic ritual in the general context of syncretic multi-element complex of ceremonial shamanistic practice.

\section{Methods and Materials}

In the context of the syncretic complex of ceremonial shamanistic practice, musical component of the artistic field of the shamanistic ritual was studied on the basis of an extensive historical analysis of materials provided by anthropologists and field studies. In our case, it was supplemented by a hermeneutic analysis of the components of Kazakh musical culture (first practice in such studies).

\section{Magico-religious aspect of the shamanistic practice}

In terms of the specific aspect of culture, manifested in the syncretism of various art forms, shamanistic ritual was determined by the single creative impulse, worldview, order, and way of thinking. Primitive syncretism outlined the borders and content of the artistic field of the shamanistic ritual. In the traditional shamanistic worldview, melodies (song and instrumental) were intended to create a connecting channel between worlds, which enhanced the contact between the material world and the world of the supernatural. It is worth bearing in mind that in the mythological consciousness of traditional culture, these worlds were divided by spatial, rather than ontological, borders. Music helped to conjure images of spirits and delve into the world of sensations typical for ecstasy. Thus, shaman mimicked the sounds and behavior of the totem animals and birds of the tribe, the image whereof, according to the understanding of the tribesmen, was taken by the spirits, who visited humans.

During the ritual, shaman was mimicking the behavior of an eagle and hopping around the yurt, casting spells, and then he was climbing on the dome of the yurt, imitating the animal, which characteristics he represented Such an altered mental state was a form of ritualistic behavior (Fedorova, 2001).

The presence of a special medium was necessary for human beings to communicate with the spirits. The shaman was such a medium, whose responsibility was to serve the spirits that were protecting his tribe (Hoppal, 1995).

The shamans were responsible for performing the entire range of tribe's magical practices. This has been an honorable social role that was about worshipping the gods in the Upper world, subduing the evil carnivorous spirits of the Lower World, and asking for the "earth masters"' mercy in the Middle world. This obliged the shaman to perform funeral rites - another element of his social function in the tribe (Ashiraliyev, 2008).

Shamans attended sick people and weddings. In the first case, they acted as doctors, in the second - as priests and sorcerers, predicting the future of the newlyweds (Urmanbetova, 1997). People sought the shaman's help in case of infertility, prolonged labor, branding of livestock, cleansing or consecration of homes or tools of trade. Shamans were asked to enchant amulets, give luck during hunting or animal breeding. They attended funerals, military expeditions, etc. Such inclusiveness stemmed from the age of primitive syncretism, represented in the ritualistic complex in its natural and organic form (Seregin, 2014). 
The ideological aspect of the shamanistic ritual reflected the system of beliefs regarding birth, life, and fate of the human being after death, his or her soul, afterlife, and the otherworld. According to shamanism, the human being does not die, since his/her life goes on in the sky - a place of supreme spiritual incarnation. Faith in human souls continuing their existence in an incorporeal form is expressed by the fact that in the mind of an archaic person, existence implies not only earthly and tangible world, but also a different, heavenly, spiritual, and intangible one (Douglas, 2011).

Shamans communicated with the spirits in a state of ecstasy, during which the guardian spirit could merge with the shaman into a single entity and manifest itself in him (Hoppal, 1995). In order to resist evil mystical forces, shamans sought help from similar forces, opposing evil spirits with the mystical powers of their witchcraft. Assaults of invisible forces and the threat of evil supernatural machinations left the shaman with no other way of protecting himself other than appealing to the supernatural world. Spirits' help gave shamans the supernatural powers to make one successful in one's craft, predict the future, ward against misfortunes, find lost things, determine the causes of diseases, cure the ill, and guide the spirits to the afterworld (Pearson, 2002).

In such ecstatic state, shaman could have visions that he controlled by the force of will and concentration. They allowed him to conjure in his imagination and clearly see the spirits of ancestors. This exalted and extremely nervous state was not only achieved conscientiously, but also controlled according to traditional rules. In the world of visions, shaman experienced hallucinations that corresponded with the goals of the ritual. At the same time, he keeps a strong connection with the real world and reacts to real people. After the séance, shaman told the witnesses about the spirits he communicated with and retold their advice and predictions (Ashiraliyev, 2008).

Thus, organic interaction of all ritual elements in a holistic structured complex constituted the syncretic essence of the shamanistic ritual, where the religious and mystical aspects integrally united with the artistic and esthetic ones.

\section{Artistic aspect of the shamanistic practice}

In addressing the spirits, shaman usually sang and played percussion or string musical instruments impromptu. Various impromptus associated into multi-element syncretic complexes, where the melody, lyrics, moves, and dances were combined with a special costume, composition, instantaneous change of setup, live animals and birds, etc.

Instrumental impromptus always had a certain magical and symbolic meaning in the context of dramatic ritual, thus ordering the multi-element complex.

In this regard, it is worth distinguishing the impromptu interludes that established the plot, emotional mood, and nature of the drama. Shaman's honed artistic technique thrilled the tribesmen and could be an object of worship.

The world that the shaman manifested was complex and in constant mythological establishment; it had no static elements - everything was in development, struggle, movement, and transition from one into another, while simultaneously being logical and beautiful. Despite all the attention to small details, its interpretations were always dominated by a single whole. During the impromptu, shaman bears in mind the plan of the entire work, creating an amazingly perfect sound form. 
The lyrics and stories also played a major role in the ritual. They began with summoning recitative phrases, followed by a quick main part accompanied by developed melodic movement with large intervals and contrasting sound combinations. They culminated in a theme that included a flow of melodic phrases. The song had a distinctive rhythmic versification, formed by multiple secondary inserts: words, interjections, and vowels. The rhythm and time of the song depended on the rhythm of the poem. The ritual began with a rhythmically determined melody; during the middle part, which was devoid of regular metrics, the rhythm featured long pauses. The song and recitative intonation and the combination of verbal and vocal aspects made for an extended informative expression by expanding the reserves of imaginative concretization and the power of influence on people.

The shaman had to remember not only the sequence of sounds in the melody, but also the means through which those sounds were made - finger notation and articulation. This required exceptional aural memory, quick movements, and masterful finger work. Skillful basky endowed the musical instrument with a live expressivity of voice and emotional warmth (Yanovsky, 1907).

Dance was the second important component of the syncretic shamanistic practice. Fragments of scenes that resemble dance moves of ancient shamans are indicative of the fact that the ancestors of modern Central Asian nations, who lived in the third-first centuries BCE, were masters of the syncretic art of dance. Diverse postures and moves that reflected the archaic totemic and mythological beliefs, ritualistic, magical, ceremonial, and mysterious images form a holistic picture of the spiritual world. The dance is closely related to the religious beliefs of shamans - ritualistic dances performed cosmological functions in the light of the abovementioned three-level perception of the world.

Thus, the artistic aspect of shamanistic practice required a developed imagination and creative giftedness. Shamans used the entire wealth of the oral folk art to develop a personal style. They also performed the functions of a storyteller by combining the poetic gift with knowledge of myths and legends. The functional role of each musical instrument that accompanied the shamanistic ritual was dominated by the correlation of ritual and worldview principles that the ritual was based on. From this perspective, we should bear in mind that in the traditional culture of Central Asian peoples, a person with a gift of musical and poetic improvisation was considered as one blessed by the spirits. Kazakh nomads believed that the poetic and musical gift was a sign of the person being blessed by the spirits of ancestors. This is evidenced by the phrases "аркасы бар" (has a back) and "арка козады" (moving back), which meaning lies in the Kazakh ideas about space that emerged under the influence of the South. After the Mongolian invasion, this cult spread across the entire steppe, including the territory of modern Kazakhstan (Sembin, 2013). According to this cult, world quarters were found by facing south, but not north, as it was in European countries. In this position of the observer, south is forward, east is left, west is right, and north is back. The north was called the arc ("арка") - the backside or back According to the traditional beliefs of Kazakh nomads, the "world of the dead" (world of ancestors) was located somewhere in the north or west (Sembin, 2013). Thus, the phrase "аркасы бар" has two meanings: 1) a person with special skills given by the ancestors, who live in a world opposite the world of the living; 2 ) a person, protected by the ancestors.

\section{Functions of the sacred musical instruments in the shamanistic ritual}

During the ritual, Central Asian shamans used various musical instruments, which intended purpose was to serve as a medium between the world of humans and the world of Gods [19]. The main instruments used by Tenrgians involved the Kazakh kobyz (less frequently - a plucked string 
dombra) and the Kyrgyz plucked string komuz (dombra). Other instruments used by Kazakh and Kyrgyz shamans included the idiophonic asatayak and the shaman tambourine.

\section{The Kobyz}

The kobyz is one of the most ancient string bow instruments in the world. It laid the foundation for such European bow instruments as the violin and the cello. Many similar instruments were also used by other nomadic people of Central Asia: the Kyrgyz people used the kayak; the Mongolian people the morin khuur or the khuur; the Tuvinian people used the igil (Bakhman, 1972). The most ancient musical instruments of such type have a curved form that is similar to a bow, a fully leather body, strings and bows made of horsehair. At that, the kobyz has the most archaic form among the similar traditional instruments.

The kobyz is carved from a single piece of wood. Such an ancient way of making musical instruments is based on the belief of many peoples that only a single piece preserves the singing soul of the tree, which sounds through the instrument (Amanov \& Mukhambetova, 2002). Kobyz has a double bucket-shaped body, a short, arcuate curved neck, a large flat head and consists of a hollowed, double-hulled blister with a handle attached to it at the top and with a bottom outlet for approval of the stand. The head has hanging metal rings, bells or plates. Two strings, imposed on kobyz, are made out of a bundle of 30-6o horsehairs. Their combination wih the hollow body produces a deep and overtone-rich timbre. The kobyz is played vertically with a bow (Amanov \& Mukhambetova, 2002).

One can value the sound of kobyz by comparing it with the sound of violin. The violin with its long history has a very refined sound, devoid of even the smallest side tones and with smoothed overtones. Sound specificity of the kobyz lies in the unique deep and low timbre. Its vibrating tones have a significant psycho-physiological effect.

The sound of the kobyz is considered as polyphony, where the main tones are accompanied by vibrating side tones, distinctive overtones, and background hissing noise. Such depth and richness of timbre reflects the spatial ideas of Kazakh nomads in regards to the multi-level structure of the universe. In playing on the strings with a bow of horse hair, bakses could make sounds imitating the surrounding nature - wing beat, howling wolves, wind noise, and even the sound of released arrows.

The conceptual content of the Kazakh kobyz construction also has a cosmic and spatial meaning. The spatial structure of the Universe that is embodied in the kobyz makes it an iconic object that is used to worship the cosmic harmony: the bass (the head) and its two "ears" that adjust the strings represent the Upper world. The body, the hollow part of the instrument, resembles two cerebral hemispheres and represents the Middle world. The bottom part of the instrument represents the Lower world - the water of primeval Chaos. According to Kazakh legend, such an embodiment allows the shaman to use the as a tool that allows moving through space and time (Amanov \& Mukhambetova, 2002). In science terms, this legend and other similar tales are indicative of the shamans having the skills of hypnosis, which could affect masses of people.

The kobyz is related to the mythical figure of the first shaman - Korkut (known as Korkud among Ghuzz Turks), who, according to the legend, invented this musical instrument. Literary and scientific sources regard Korkut as a prophetic singer, a saint elder, a healer, a witchdoctor, and a wise shaman; a family elder and a priest that combined the characteristics of a sorcerer, prophet, sage, and musician. Korkud, the storyteller, councilor to the khan, a sorcerer, a witchdoctor, and a 
wise patriarch, was also characterized as a wise prophet among the Oghuz - all his predictions came true (Samashev \& Chotbaev, 2012).

His image of a creator of divine music, stopping time and fascinating people, animals and even death, is one of the archetypal images in mythology. In this regard, one can recall the Greek Orpheus, Finno-Ugric Väinämöinen, the character of the Kalevala epic poetry, or Gilgamesh from the Sumerian and Akkadian epic (Zhubanov, 1958).

In realizing different ways in which the cosmic harmony was created, simultaneously uniting them all, each of the existing interpretations of the Korkut myth has sacred not only the kobyz as a musical instrument, but also the music. The nonexistence is harmonized and transformed into the cosmos only by means of music. According to the legends, world creation is associated with music and takes place once Korkut lowers his kobyz into the water of the Syr Darya River. This place became the Center of the Universe ("жер кіндігі"). The world is imbued with music, while the "center" of the world is a place where cosmic and energy forces concentrate. This explains the unique ideas of world creation among the nomads - creation through Music as the essence of Harmony (Ayazbekova, 1999). Similar notions can be found in Ancient Greek philosophy (particularly in Platonism), Confucianism (the harmony of ritualized ethos of relationships between the descendants and the ancestors), and Shivaism (the world-creating dance of Shiva). The end of the myth is also appropriate - it is related to Korkut being buried at the center of the world; thus, the shaman's grave emits the magical sounds of the kobyz (Hoppal, 1995).

Music, which was given to Korkut by Tengri himself, became a life-creating beginning and was worshipped in the culture of Turkic peoples to the point of being treated as sacred and divine. This is why the Turkic-speaking peoples worshiped the Korkut with the involvement of shamanism - bakses asked him for help during the ritual, playing melodies that he composed, according to legend.

\section{The Kyrgys komuz or dombra.}

Dombra, as a sacred musical instrument, can be characterized by a Kazakh saying: the Kazakh himself is not the true Kazakh, dombra is the true Kazakh. This instrument is an important part of the Kazakh cultural heritage, as it helped to preserve through the centuries the ancient kui (instrumental pieces), which language is understandable even for modern Kazakhs. This is evidenced by the fact that the Kazakh language has not changed under the influence of Islam, and is purely Turkic (Yanovsky, 1907).

Dombra is a string plucked musical instrument, made from different types of wood. There are two types of its body shape- pear-shaped (ancient) and triangular (modern). The neck, divided with frets, is attached to the body; two strings are tuned - bass and prima. Traditional strings are made of mutton or goat sinew; they have a unique tone. However, they were replaced by strings made of a fishing line, as it was considered as more suitable for sounding. A stand (as a violin one) is the most important part for the sound of dombra is. It transmits the string vibrations to the deck and creates the first resonant circuit on the path of vibrations from strings to the body. The stand is a key to the sound of dombra, as the sound tone, strength and cleanliness depend on stand's .form, qualities, settings and weight (Zhitetsky, 1893).

There are many legends about the origin and the modern form of the dombra. The first popular legend is about two brother giants that left a stamp of dombra in the rock in the heat of a quarrel. Based on the stamp, people could recreate this musical instrument for themselves. According to another legend, dombra has two strings and an opening in the middle because of the 
evil Khan, who ordered to spoil the strings of the instrument and pour hot lead into its middle. The science proves the ancient existence of dombra by presenting the rock painting (Neolithic Period), found high in the mountains in the Almaty region (Kazakhstan). It depicts a tool very similar in shape to the dombra. Thus, scientists concluded that the prototype of modern dombra is more than 4000 years old, and it is one of the first plucked instruments (Akishev, 1978).

Similar instruments are common throughout the world. They include the Russian balalaika and the Ukrainian kobza - instruments with a similar shape and origin, but coming from an entirely different cultural context. In terms of modern musical instruments, the komuz is most similar to the lute.

Dombra is the most popular musical instrument among the Kazakhs. It was one of the main ritual attributes. Nowadays, modern Kazakh dancers use dombra as a leading traditional musical instrument (there was even an elektrodombra created in 2012) (Alekseeva \& Nazhmedenov, 200o). As a universal instrument in sounding, dombra was helping the shaman to communicate with the spirits, to fall into ecstasy, and to play folk songs that they sang at weddings and other solemn events. Modern dombra is both a solo and ensemble instrument. Just two of its strings create musical stories that can convey human feelings and experiences.

In terms of Sacredness, dombra structure is as good as the kobyz one. Its heavenward form symbolizes the vertical temporal movement of the Universe. In the syncretic unity of the artistic field of the shamanistic ritual, it is correlated with the vertical dance moves of the shaman. The form of the komuz is related to the meditational trips of the shaman into the Upper world of the spirits that demand worshipping (Amanov \& Mukhambetova, 2002). Dombra symbolizes the unity of human heart and mind, its music is the product of their equality.

\section{Kazakh dangyra and asatayak}

Dangyra (Kazakh shaman tambourine) and asatayak are two basic instruments of the shamanistic ritual. Its importance for shamanistic practice is hard to downplay, since all the basic shaman's actions involve its use. Dangyra is a percussion musical instrument that is hit with a mallet. Other peoples had a similar percussion instrument: kaniira - Indian frame drum, doira - Tajik tambourine, dap - Uighur tabbourine.

The tambourine has a frame covered with leather on the one side with numerous jingles, chains, rings, and plates mounted inside. In the shamanistic ritual, it was used as part of various images: shaman's riding animal; as a bow, used by him against an evil spirit; as a boat, used by him to travel the seas and rivers during the ritual. It creates a simple vibrating rhythmic framework that organizes moves. Its sound pattern symbolizes the mythological cycles and closure of existence on

itself. The rhythm of the tambourine is in sync with the heartbeat and makes it easier for the participants of the ritual to enter a meditative trance.

The asatayak, which was generally used together with the tambourine, is another Kazakh and Old Turkic percussion musical instrument. It is a rod with a flat head decorated with an ornament and metal pendants. In the shamanistic practice, the asatayak was almost always used together with the konyrau - ritualistic bells (Akishev, 1978). Other nations also had instruments that were similar to the asatayak, for example - the Uzbek sapai, the Kyrgyz shyldyrak, and the Japanese sakujo.

The conceptual aspect of the asatayak is related to the ritualistic cleansing mallet (a sound amulet and a talisman) which was common among peoples with a traditional culture. It is worth 
mentioning the tugs used for ritualistic purposes by Genghis Khan's army, the Ottoman Empire, the Polish-Lithuanian Commonwealth, and Cossacks. The asatayak completed the conceptual image of the Universe that was expressed in the sacred musical instruments of Kazakh and Kyrgyz shamans.

If the tambourine represented the rhythmic foundation of creation, then the asatayak, similarly to the dombra, pierced the world vertically and brought purification and renovation. The heavy rhythmic architectonics of the tambourine was complemented by the ringing that restored harmony.

\section{Conclusions}

We have studied shamanism as a synthesis of religious ideas that included elements of monotheism (the transcendence of Tengri as the all-encompassing impersonal beginning), worshipping of the Sky, ancestral spirits, and natural phenomena, all of which were expressed in artistic syncretism. Central and Northern Asian shamanism was not an original phenomenon, devoid of external influences; however, the merit of Siberian and Central Asian shamanism is that it is a structure, which elements exist independently of each other in other parts of the world. In these regions they were united into an original ideology that served as the foundation for specific practices.

The shamanistic ritual, which was the result of creative syncretism in the shamanistic practice, was given the pride place. In the historical and cultural respect, there is a distinct connection between the shamanistic ritual and other forms of art, which is seen in the acts of syncretic synchronous functioning.

In the context of syncretic multi-element complex of the shamanistic practice, musical component of the artistic field of the shamanistic ritual is characterized by the following features:

1) determination by religious traditions of Tengrism, which affected the content and form of instruments, peculiarities of their sound, and the impromptu nature of performance.

2) four musical instruments that had the greatest significance for the musical component of the shamanistic ritual were the kobyz, the dombra, the tambourine, and the asatayak. They reflected the traditional spatial ideas of Kazakhs regarding the order of the Universe and formed a holistic structure of sacred meanings, according to its formal attributes and peculiarities of sound.

3) there are two conceptual couples of sacred shamanistic musical instruments, the form and sound whereof embodied the mythological perception of the Universe that was typical for Turks. The main couple is the horizontal kobyz and the vertical dombra, which symbolize the space and time continuum; the secondary couple is the tambourine and the asatayak, which symbolize the structure and harmony of the world. In these conceptual contexts, they were part of the musical aspect of the single multi-element syncretic complex of the shamanistic ritual.

4) discovered sacred meanings of musical instruments became relevant not separately, but within the context of syncretic multi-element complex of the shamanistic ritual, alongside the main cultural, magical, religious, dramatic, artistic, and utilitarian (including medical) activities.

Musical instruments, without which the shamanistic ritual would be impossible, bore a symbolic load - they were a sacred means of conveying information about the structures of the world and the depths of the human mind. Having been invented by mythical ancestors, they were perceived by people of traditional Central Asian societies as capable of magical influences and a connecting channel between worlds, performers of the role of a "vehicle" that facilitated the meditative trip of the baksy into the spirit world. Gestures, actions, dances, costumes, lyrics, 
music, musical instruments - all this combined to create a dramatically developed magical performance that unfolded in space and time thanks to the talent and artistic mastery of the performer - the shaman.

Accordingly, each component of the syncretic complex of shamanistic practice separately and the entire complex are subject for further research. Based on the artistic component, we can also distinguish such components as drama, dance, pantomime, etc. that contain a variety of multidimensional meanings that require special study in the context of the magico-religious aspect of the entire complex.

\section{References}

Akishev K. A., (Issyk Kurgan. Moscow, 1978).

Alekseeva L.A., \& Nazhmedenov Zh., Musical structure features of the Kazakh dombra. Kazakh culture: research and exploration. (Collection of scientific articles, Almaty, 200o).

Amanov B., \& Mukhambetova A.I., The calendar and peculiarities of time in the Kazakh culture. Kazakh Traditional Music and the Twentieth Century. (Almaty: Dayk-Press, 2002).

Amanzhol B., Musical traditions of tengrianity. (Central Asian Journal of Art Studies. Volume 1, No. 1, 2016).

Ashiraliyev J.A., The methodological aspects of studying nomadic culture. (Bishkek, 2008).

Ayazbekova S., The ethnic worldview: Korkut-ata and the philosophy of Kazakh music. (Almaty, 1999).

Bakhman V., Central Asian sources on the birthplace of string instruments. The Music of Asian and African Peoples. (Moscow: Soviet Composer, 1972).

Bezertinov R., Tengrism - the religion of Turks and Mongols. (Kazan, 2006).

Douglas L., The Nature of Nomadism A Comparative Stud of Pastoral Migrations in Southwestern Asia. (The University of Chicago. Departament of Geography. Research Paper 2011).

Eichhorn A.F., Materials on music and ethnography. Music Folklore Studies in Uzbekistan. (Tashkent, 1963).

Fedorova N., Shamans of Western Siberia. The Archaeology of Shamanism. Neil S. Price. (London and New York: Routledge, 2001).

Flaherty G., Shamanism and the eighteenth century. (Princeton University Press, 2014).

Hoppal M., Shamanism in Siberian. Shamanism in Performing Arts. (Budapest: Akademiai Kiado, 1995).

Hultkrantz A., The Place of Shamanism in the History of Religions. - Shamanism Past and Present. Part 1. (Budapest, Ethnographic Institute Hungarian Academy of Sciences, 1989).

Ksenofontov G.V., Shamanism. (Yakutsk: North-South Publisher, 1991).

Margulan A.Kh., \& Lizunova Ye.V., On the bearers of ancient Kazakh culture. Collection of Articles Dedicated to the $60^{\text {th }}$ Anniversary of M.O. Auezov. (Alma-Ata: Kazgoslitizdat, 1957).

Nicholson Sh., Shamanism. (Quest Books, 2014).

Novik Ye.S., The shamanistic ritual as a dramatized description of the universe. (Collection of Research Papers on Secondary Modeling Systems, 1973).

Pearson J. L., Shamanism and the Ancient Mind: A Cognitive Approach to Archaeology. (Alta Mira Press, Lanham, Maryland, 2002).

Radlov V.V., The Turkic dialect dictionary. (Oriental Literature Publishing, 1959). 
50 | Sacred Functions of Musical Instruments in the Creative Syncretism of Shamanistic Ritual

Samashev Z., \& Chotbaev A., Drevnetyurkskiy Voin-Muzykant Iz Kazakhskogo Altaya. Srednevekovaya Gorodskaya Kul'tura i Kochevaya Tsivilizatsiya Bas-seyna Reki Ural. (Ural'sk: Gylym, 2012).

Sembin M., The secret of the Turkic and Mongolian land: origins and symbolism of geographic names. (Almaty, 2013).

Seregin H.H., The dynamics of the social systemof early medieval Turks of the Altai-Sayan region and Central Asia (of archaeological materials). (The News of Altai State University, 2014).

Urmanbetova Zh.K., The Kyrgyz culture in the historical philosophy projection. (Bishkek: Nauka, 1997).

Valikhanov Ch.Ch., Traces of shamanism among the Kyrgyz people. Collected works. (Alma-Ata, 1961).

Yanovsky A.E., Kyrgyz people. Brockhaus and Efron Encyclopedic Dictionary. (St. Petersburg, 1907)

Zhitetsky I., Essays on the life of Astrakhan Kalmyks: Ethnographic observations of 1884-1886. (Moscow, 1893).

Zhubanov A.K., The strings of centuries. (Alma-Ata: Kazgoslitizdat, 1958). 